\title{
Circular Economy and Industry 4.0: One-Way or Two-Way Relationships?
}

\author{
Marek Cwiklicki, Magdalena Wojnarowska
}

\author{
Cracow University of Economics \\ ul. Rakowicka 27, 31-510 Krakow, Poland \\ E-mail.marek.cwiklicki@uek.krakow.pl; magdalena.wojnarowska@uek.krakow.pl
}

cross'ref $\mathrm{http}: / / \mathrm{dx}$.doi.org/10.5755/j01.ee.31.4.24565

\begin{abstract}
The ability of Industry 4.0 to help solve complex economic and social problems and implement complex concepts is assessed. Currently, one of the greatest challenges is the integration of the circular economy (CE) into real business practices. However, the link between these two ideas is not fully recognised, causing an interpretative dilemma. Therefore, the aim of this paper is to identify the relationships between the CE and Industry 4.0. For this purpose, we performed a systematic literature review and content analysis of selected articles indexed in Scopus, Web of Science, ScienceDirect, and EBSCO. In total, 32 papers published during the period 2017-2020 were analysed. The findings show a one-way relationship, i.e., Industry 4.0 leads to a CE, and a two-way relationship, indicating synergy between these concepts. The key spheres of the CE in terms of Industry 4.0 are the recycle and reuse strategy applied in smart production and a sustainable supply chain. This study demonstrates the importance of company (micro) and industry (meso) levels as application areas. The most promising digitalisation tools of Industry 4.0 are the Internet of Things (IoT) and Big Data Analytics. The article concludes with the limitations of the study and a formulation of directions for future research.
\end{abstract}

Keywords: Circular Economy; Industry 4.0; Relationship.

\section{Introduction}

The implementation of a circular economy (CE) requires changes in business models and society. Furthermore, the creation of new technological solutions based on information and communication technology appears to be a promising facilitator for the introduction of $\mathrm{CE}$ to the business realm. As explained in the following section, few studies investigated the relations between these two ideas. The links between CE and Industry 4.0 have not been fully discovered, and thus, the potential of merging knowledge regarding these concepts is not fully realised by practitioners and businessmen.

The novelty of this paper lies in the presentation of an in-depth analysis of the relations between CE and Industry 4.0 studied and analysed in recent scholarly publications. Thus, this paper explores the gap in the identification of the potential utilisation of common areas related to these two multidimensional ideas. Starting from the level of ambiguous umbrella concepts enables the deconstruction of their meaning and identification of their relations according to a top-down approach, which is the opposite of existing analyses. For example, Okorie et al. (2018) provided a synthesis derived from a detailed term analysis, and Rosa et al. (2020) discussed mixed macro and micro topics. This deductive reasoning allows for the precise recognition of the key elements building compound names, such as Industry 4.0 and $\mathrm{CE}$.

The aim of this paper is to identify the links between the circular economy and Industry 4.0 based on a systematic review of peer-reviewed scientific papers. The reason for choosing this topic is the increasing role of solutions associated with the Fourth Industrial Revolution, i.e., Industry 4.0, such as artificial intelligence, robotics, the
Internet of Things (IoT), autonomous vehicles, 3D printing, nanotechnology, and biotechnology, in social-economic development (Schwab, 2016). The CE is perceived as a new sustainable economic paradigm (Geissdoerfer, Savaget, Bocken, \& Hultink, 2017) involving an economic system relying on the reuse, recycling, and recovery of materials in production, logistics and consumption processes (Kirchherr, Reike, \& Hekkert, 2017). The CE's foundation is product design with an emphasis on the so-called 'design for recycling' as during this stage, decisions are made regarding the extent to which recyclable materials will be used. The main objective of the design for recycling is to achieve a maximum reduction in raw material production, utilise recycled materials, and achieve the highest level of recyclability after the end of the product life cycle. Designing in a manner that will enable waste materials with specified properties to be recovered and used again in the manufacturing process or by others is essential (de Aguiar et al., 2017).

The abovementioned short explanation of these two concepts raises a question regarding possible symbiosis, i.e., one idea is supported by the other, with an attempt to identify the direction, i.e., broadly understood liaisons between these ideas.

This research is guided by the research objective, which is to identify the relations between $\mathrm{CE}$ and Industry 4.0 existing in the following different levels from a socialeconomic perspective: enterprises (cf. F. Garcia-Muina, Gonzalez-Sanchez, Ferrari, \& Settembre-Blundo, 2018), businesses (cf. Ming-Lang Tseng, Tan, Chiu, Chien, \& Kuo, 2018), and the national economy (cf. Ming-Lang Tseng et al., 2018). To achieve this research objective, a systematic literature review was chosen as the main research method. 
The following two research questions are derived from the above objective:

RQ1: What is the direction of the relationships between CE and Industry 4.0 ?

RQ2: What are the key spheres necessary for introducing CE supported by Industry 4.0 technologies?

To answer these research questions, we performed a systematic review of the literature indexed in Scopus, Web of Science, ScienceDirect, and EBSCO. In total, 32 papers published during the period 2017-2020 were analysed.

This paper contributes by highlighting the symbiosis between Industry 4.0 and $\mathrm{CE}$ and demonstrating the importance of industry and sustainable supply chains with special reference to the IoT and Big Data Analytics. Moreover, we propose new theoretical frameworks of the analytical structure of CE (3R, ReSOLVE, and CE key components) and Industry 4.0 (list of technologies). Our study differs from previous literature reviews referring to CE and Industry 4.0 by applying a top-down approach, adopting our own analytical tools and including recent literature related to rapidly developing concepts.

\section{Background}

Theoretically, the following three possible variations in direction are possible: CE leads to Industry 4.0, Industry 4.0 impacts CE, or both concepts are interrelated. The first two possibilities are described by Knudsen and Kaivo-oja (2018). These authors explain that the first possibility is using the CE to create Industry 4.0; in contrast, the second possibility is using Industry 4.0 to build a CE. However, the initial studies in this area indicate that only a few studies concerning merging Industry 4.0 and $\mathrm{CE}$ have been published (Knudsen \& Kaivo-oja, 2018). The nature of these studies is explorative as they describe only common points.

For example, the IoT, which is a characteristic of Industry 4.0 in terms of $\mathrm{CE}$ and waste recycling, can be applied in the packaging industry as the concept "Internet of packaging". However, searching for this phrase in Google Scholar yields only 14 (sic!) results (data on 5.4.2020). This issue is discussed in corporate blogs presenting the benefits of this solution ('The Internet of packaging is the future of consumer brands', 2019). The Internet of packaging is positioned at the level of companies in the logistics area. The direction of influence could be as follows: Industry 4.0 leads to a CE. This direction is also visible in the World Economic Forum Report, which indicates material flow and scaling of technology for the use of CE (WEF, 2019). Therefore, the initial research conducted for the purpose of this paper shows the following direction: Industry 4.0 enhances CE.

\section{Methods}

We employed a systematic literature review as the main research method. Regarding the data sources, we chose journal and book databases that are internationally recognised whose coverage is multidisciplinary and relevant to our research areas of CE and Industry 4.0. We used the following four databases as data sources: Scopus, Web of Science, ScienceDirect, and EBSCOhost. This choice is justified by a comparison with other systematic reviews performed in this topic area (e.g., Okorie et al., 2018; Rajput \& Singh, (2019); Rosa et al., 2020).

The chosen search strategy was "circular economy" AND "Industry 4.0". We chose general terms because we sought to identify papers in which these two words were used not as synonyms or detailed features associated with these concepts. For example, a more specific search performed by Okorie et al. (2018) includes particular terms associated with $\mathrm{CE}$, such as reuse or recycle, and Industry 4.0 , such as digital technologies or digital intelligence. In our research design, we examined papers adopting more comprehensive perspectives rather than narrowly approaching CE and Industry 4.0.

The search strategy was applied to the articles' titles, abstracts, and/or keywords (e.g., TITLE-ABS-KEY field in Scopus and Topic field in Web of Science) with no additional limitations regarding full paper availability, time period, etc. We did not establish additional criteria because the number of records generated by the search using the default settings was appropriate for a content analysis. Figure 1 depicts the numbers of records obtained in each step undertaken while selecting papers.

After removing the duplicate records, 74 papers were identified and qualified for the assessment. After reviewing the titles, abstracts and full-text, we excluded 38 papers from further analysis due to the following reasons: being a conference announcement or call for papers, unrelated to $\mathrm{CE}$ or Industry 4.0 (keywords did not appear in the main text of the paper), not written in the English language, and lack of full text availability. Finally, 32 papers were eligible for the content analysis; however, two papers were treated as one paper as the two versions included the same main content. Table 1 provides a list of the analysed papers. A short descriptive analysis is presented in the following section of this paper. This table covers the publication years, research areas, levels of analysis, research methods, paper types, and different types of businesses or companies mentioned.

To identify proxies for $\mathrm{CE}$ and Industry 4.0, we reviewed the definitions of these two categories. These definitions enable us to create a theoretical framework for structuring the selected papers.

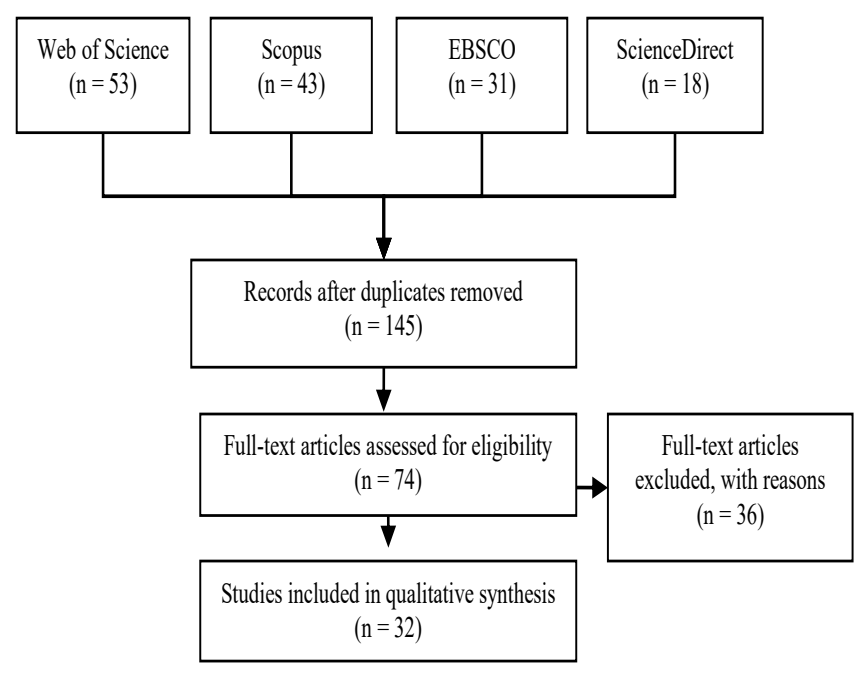

Figure 1. Study Selection Process Stages 
We supplemented the list by adding components associated with CE, such as LCA (Life Cycle Analysis), eco-design, circular business models and resources efficiency, which were considered key complements to the criteria. Regarding the second concept, i.e., Industry 4.0, we established a list of technologies based on review papers (Okorie et al., 2018; Rosa et al., 2020), which were used as coding categories. The list includes Additive Manufacturing, Big Data and Analytics, Cloud Manufacturing, CyberPhysical Systems, IoT, and Other (none of the above).

List of Analysed Papers Concerning the Circular Economy and Industry 4.0

Table 1

\begin{tabular}{|c|c|c|c|c|c|}
\hline No & Reference & Focus & Level of analysis & Research method & Paper type \\
\hline 1 & Bag et al. (2020) & $\begin{array}{l}\text { Procurement } 4.0 \text { influences circular economy } \\
\text { performance }\end{array}$ & global & survey & empirical \\
\hline 2 & $\begin{array}{l}\text { Belaud et al. } \\
(2019) \text {. }\end{array}$ & $\begin{array}{l}\text { By-product supply chain is supported by big data } \\
\text { analytics }\end{array}$ & industry & case study & empirical \\
\hline $3 / 4$ & $\begin{array}{l}\text { Bressanelli et al., } \\
(2018 \mathrm{a})\end{array}$ & Business model and product-service appliance & company & case study & empirical \\
\hline $3 / 4$ & $\begin{array}{l}\text { Bressanelli et al., } \\
(2018 \mathrm{~b})\end{array}$ & Product-service system business models & company & case study & empirical \\
\hline 6 & $\begin{array}{l}\text { Chauhan \& Singh } \\
(2019)\end{array}$ & $\begin{array}{l}\text { Implementation of Industry } 4.0 \text { in supply chain } \\
\text { management studies }\end{array}$ & company & $\begin{array}{l}\text { systematic literature } \\
\text { review }\end{array}$ & theoretical/review \\
\hline 7 & $\begin{array}{l}\text { Chauhan, Sharma, } \\
\text { \& Singh (2019) }\end{array}$ & Integration of Industry 4.0 and CE business models & company & $\begin{array}{c}\text { interpretative } \\
\text { analysis/framework }\end{array}$ & conceptual \\
\hline 8 & Dau et al. (2019) & Healthcare sustainable supply chain 4.0 & company & case study & empirical \\
\hline 9 & $\begin{array}{l}\text { de Oliveira \& } \\
\text { Soares (2017) }\end{array}$ & CE-enabled product lifetime management & industry & $\begin{array}{l}\text { conceptual } \\
\text { framework }\end{array}$ & conceptual \\
\hline 11 & $\begin{array}{l}\text { Garcia-Muina et al., } \\
\text { (2018) }\end{array}$ & Conceptual model of a ceramic tile company & industry & case study & empirical \\
\hline 12 & $\begin{array}{l}\text { Garcia-Muina et al., } \\
(2019)\end{array}$ & Eco-design & industry & case study & empirical \\
\hline 13 & $\begin{array}{l}\text { Halse \& Jæger } \\
\text { (2019) }\end{array}$ & Barriers to CE adoption & company & interviews & empirical \\
\hline 14 & $\begin{array}{l}\text { Jabbour et al., } \\
(2018)\end{array}$ & $\begin{array}{l}\text { Sustainable operations management }(\mathrm{SOM}) \text {-- a } \\
\text { pioneering roadmap }\end{array}$ & $\begin{array}{l}\text { Company/ } \\
\text { industry }\end{array}$ & $\begin{array}{l}\text { conceptual } \\
\text { framework }\end{array}$ & conceptual \\
\hline 15 & $\begin{array}{l}\text { Karjalainen et al. } \\
(2019)\end{array}$ & $\begin{array}{l}\text { Implications of peer-to-peer activities for the } \\
\text { development of CE }\end{array}$ & global & foresight workshop & empirical \\
\hline 16 & $\begin{array}{l}\text { Kouhizadeh, Zhu \& } \\
\text { Sarkis (2019) }\end{array}$ & Blockchain applications & industry & multiple case study & empirical \\
\hline 17 & $\operatorname{Lin}(2018)$ & Product design/concept/model & industry & case study/concept & conceptual \\
\hline 18 & $\begin{array}{l}\text { Manavalan \& } \\
\text { Jayakrishna, (2019) }\end{array}$ & Sustainable supply chain & company & case study & empirical \\
\hline 20 & $\begin{array}{l}\text { Nascimento et al., } \\
(2019)\end{array}$ & $\begin{array}{l}\text { Circular smart production system (CSPS) business } \\
\text { model }\end{array}$ & global & $\begin{array}{c}\text { systematic literature } \\
\text { review/focus }\end{array}$ & empirical \\
\hline 21 & Okorie et al. (2018) & $\begin{array}{l}\text { Synergistic and integrative CE-DT framework for } \\
\text { future research }\end{array}$ & global & $\begin{array}{l}\text { systematic literature } \\
\text { review }\end{array}$ & theoretical \\
\hline 22 & Pham et al. (2019) & Potential of Industry 4.0 for implementing a CE & company & case study & empirical \\
\hline 23 & $\begin{array}{l}\text { Rajput \& Singh } \\
(2019 a) \text {, }\end{array}$ & $\begin{array}{l}\text { Identification of enablers and barriers linking } \\
\text { Industry } 4.0 \text { and } C E \text { to implement a supply chain }\end{array}$ & company/industry & survey & empirical \\
\hline 24 & $\begin{array}{l}\text { Rajput \& Singh } \\
(2019 \mathrm{~b})\end{array}$ & Identification of Industry 4.0 barriers to $\mathrm{CE}$ & country & $\begin{array}{l}\text { systematic literature } \\
\text { review }\end{array}$ & theoretical \\
\hline 25 & $\begin{array}{l}\text { Rejikumar et al. } \\
(2019)\end{array}$ & Attributes of Industry 4.0 & global & $\begin{array}{l}\text { systematic literature } \\
\text { review } \\
\end{array}$ & theoretical \\
\hline 26 & Rosa et al. (2020) & Relation between I4.0 and CE principles & company & $\begin{array}{l}\text { systematic literature } \\
\text { review }\end{array}$ & theoretical \\
\hline 27 & $\begin{array}{l}\text { Ruohomaa, } \\
\text { Kantola, \& } \\
\text { Salminen (2018) } \\
\end{array}$ & Bioengineering ICT and a pilot education programme & global & conceptual model & empirical \\
\hline 28 & Sarc et al. (2019) & $\begin{array}{l}\text { Contribution of digitalisation to the value chain of } \\
\text { circular economy oriented waste management }\end{array}$ & global & review/survey & empirical \\
\hline 29 & Tseng et al. (2018) & $\begin{array}{l}\text { Concepts and tools used to assist data-driven and } \\
\text { optimisation solutions in industrial symbiosis studies }\end{array}$ & industry & $\begin{array}{c}\text { interpretative } \\
\text { analysis/framework }\end{array}$ & conceptual \\
\hline 30 & Tseng et al. (2019) & $\begin{array}{l}\text { Application of the circular economy in agro-industrial } \\
\text { systems and the role of AI and multi-functional } \\
\text { computer models in the acquisition of real-time data }\end{array}$ & global & $\begin{array}{l}\text { interpretative } \\
\text { analysis/framework }\end{array}$ & conceptual \\
\hline 31 & Yadav et al., (2020) & $\begin{array}{l}\text { Measures used to overcome sustainable supply chain } \\
\text { management challenges }\end{array}$ & industry & case study & empirical \\
\hline 32 & Yang et al., (2018) & Smart remanufacturing process & industry & dual case study & empirical \\
\hline
\end{tabular}




\section{Descriptive Analysis of the Selected Papers}

In total, 32 papers were analysed, including 22 papers published in 2019, 9 papers published in 2018, 1 paper published in 2017, and 4 papers published in the first three months of 2020, highlighting the novelty of merging the terms "Industry 4.0" and "circular economy". As depicted in Table 2, according to the journal titles, "Resources, Conservation \& Recycling" was the most prominent source of the articles.

The synthesis of the research areas and categories shows an interdisciplinary approach in researching CE and Industry 4.0 (Table 3). The main areas include engineering, computer, and environmental sciences; business, management and accounting; and social sciences. This finding expresses the complex nature of the merged concept of CE and Industry 4.0, which can be studied from the perspectives of different scientific disciplines.

The authors present $\mathrm{CE}$ and Industry 4.0 with reference to the following different levels of analysis: company, industry, country, and global (generic) (Table 1). The following two levels dominate in the set of selected papers: company (micro) and industry (meso) levels. Both types constitutes $62 \%$ of all papers. This finding can be justified by concentrating on interorganisational relations mainly within or for the supply chain.

Numbers of Papers per Journal

\begin{tabular}{|c|l|}
\hline Number of papers & \\
\hline 5 & Resources, Conservation \& Recycling \\
\hline 3 & Benchmarking \\
\hline 3 & Sustainability \\
\hline 2 & IFIP Advances in Information and Communication Technology \\
\hline 2 & Journal of Manufacturing Technology Management \\
\hline 2 & Social Sciences \\
\hline 1 & $\begin{array}{l}\text { Advances in Intelligent Systems and Computing; Annals of Operations Research; Applied Sciences; Computers and Industrial } \\
\text { Engineering; Computers in Industry; Energies; International Journal of Information Management; International Journal of } \\
\text { Production Research; Journal of Cleaner Production; Management Decision; Procedia CIRP; Procedia Manufacturing; } \\
\text { Proceedings of the 27th International Conference on the Domestic Use of Energy, DUE 2019; Production Planning and } \\
\text { Control; Waste Management }\end{array}$ \\
\hline
\end{tabular}

Table 3

Subject Category of Journals Publishing Papers Concerning the Circular Economy and Industry 4.0

\begin{tabular}{|l|c|}
\hline Subject Area & No. \\
\hline Engineering & 11 \\
\hline Computer Science & 10 \\
\hline Environmental Science & 10 \\
\hline Business, Management and Accounting & 8 \\
\hline Social Sciences & 7 \\
\hline Decision Sciences & 6 \\
\hline Energy & 6 \\
\hline Economics, Econometrics and Finance & 5 \\
\hline Chemical Engineering & 1 \\
\hline Materials Science & 1 \\
\hline Mathematics & 1 \\
\hline Physics and Astronomy & 1 \\
\hline
\end{tabular}

The following types of industries are explicitly named:

- Aerospace manufacturing (Yang, Raghavendra, Kaminski, \& Pepin, 2018);

- Paper manufacturing (Manavalan \& Jayakrishna, 2019);

- Ceramic tile manufacturing (Garcia-Muina et al. 2018; 2019);

- Palm oil industry (Ming-Lang Tseng, Chiu, Chien, \& Tan, 2019);

- Footwear (de Oliveira \& Soares, 2017);

- Glass recycling industry (Lin, 2018);

- Automotive sector (Yadav, 2020);

- Agriculture by-product supply chain (Belaud et al., 2019);

- Refrigerator manufacturer (Dev et al., 2020);

- Electric scooter manufacturing (Pham et al., 2019),

- Healthcare (Dau et al., 2019).
The above list includes industries and companies that vary in terms of the complexity of their products. Thus, Industry 4.0 can be applied in businesses with different levels of technology-enhanced production. This finding also suggests the possibility to use digitalisation to support the implementation of the CE concept.

Next, the authors discuss the topic generally without relating their own considerations to more specific layers, such as company or industry. The country level was found in two papers, and one paper specifically addressed emerging economies and Brazil, while a generic description was identified in 8 papers.

\section{Definition of CE}

In the analysed papers, $\mathrm{CE}$ is defined by referring to $\mathrm{CE}$ principles and its main characteristics. For example, de Oliveira and Soares (2017) explain that CE is based on reuse, recycling and remanufacturing principles. Similarly, Tseng (2018) mentions the 3 Rs, i.e., recycle, reduce, and reuse, while Yadav et al. (2020) refer to the 6Rs, i.e., recycle, reuse, reduce, refuse, rethink and repair. Yang et al. (2018) describe CE more generally as making products as restorative and regenerative by design and maintaining their value.

Garcia-Muina et al. (2018) briefly define CE as "the economy capable of regenerating itself". In addition, other authors provide short explanations, such as closed-loop systems (Ming-Lang Tseng et al., 2019), or refer to supply chains (Rajput \& Singh, 2019a).

An analysis of the most frequently quoted definitions in the literature indicates two sources. The first definition is provided by the Ellen McArthur Foundation. In total, 9 of the 32 articles refer to this definition. The Ellen MacArthur 
Foundation explains the following: "A circular economy is an industrial system that is restorative or regenerative by intention and design" (Ellen MacArthur Foundation, 2012, p. 7). The second most frequently quoted definition was provided by Geissdoerfer et al. (2017). This definition is quoted in 8 of the 32 studied papers. According to these authors, $\mathrm{CE}$ is "a regenerative system in which resource input and waste, emission, and energy leakage are minimised by slowing, closing, and narrowing material and energy loops. This can be achieved through long-lasting design, maintenance, repair, reuse, remanufacturing, refurbishing, and recycling" (Geissdoerfer et al., 2017, p. 579).

In addition, Geissdoerfer et al. (2017) mention that this source allows them to draw conclusions regarding the significance of the proposed conceptualisation of CE by the Foundation, which was one of the first to popularise this concept. Moreover, in the aforementioned definition by Yang et al. (2018), this definition is visible.

Another explanation of CE provided by the Ellen McArthur Foundation, which is also quoted in the studied papers, is derived from a newer report under the same title as the previous as follows: "The concept is characterised, more than defined, as an economy that is restorative and regenerative by design and aims to keep products, components, and materials at their highest utility and value at all times, distinguishing between technical and biological cycles" (Ellen MacArthur Foundation, 2015b, p. 5).

Another definition, which was derived based on a synthesis performed by Prieto-Sandoval (2018) and is mentioned in the review prepared by Okorie et al. (2018), recalls the previous definition. $\mathrm{CE}$ is defined as follows: "an economic system that represents a change of paradigm in the way that human society is interrelated with nature and aims to prevent the depletion of resources, close energy and materials loops, and facilitate sustainable development through its implementation at the micro (enterprises and consumers), meso (economic agents integrated in symbiosis) and macro (city, regions and governments) levels. Attaining this circular model requires cyclical and regenerative environmental innovations in the way society legislates, produces and consumes" (Prieto-Sandoval et al., 2018, p. 613).

In an attempt to find a CE definition that includes the above propositions, we refer to Rajput and Singh's (2019a, p. 98) proposition, which states that "CE is a closed loop supply chain which focuses on the restorative and regenerative aspects".

The analysis indicates that the most frequently mentioned $\mathrm{CE}$ aspects are two elements from the 3Rs strategy, i.e., recycle (20) and reduce (17). This finding demonstrates the importance of this strategy for Industry 4.0 technologies. Optimise (16) and share (15) are the most frequently mentioned aspects of the ReSOLVE strategy. $\mathrm{CE}$ components, such as eco-design (16) and resource efficiency (14), are mentioned in approximately $50 \%$ of the analysed papers. The remaining aspects of CE were not discussed as often as the former aspects. We believe that those elements mentioned in more than half of the papers are considered the most researched.
Table 4

Frequency of the Appearance of CE Components in the Research Papers

\begin{tabular}{|l|c|c|}
\hline \multicolumn{1}{|c|}{ CE element } & $\#$ & $\%$ \\
\hline Recycle & 20 & $63 \%$ \\
\hline Reduce & 17 & $53 \%$ \\
\hline Optimise & 16 & $50 \%$ \\
\hline Eco-design & 16 & $50 \%$ \\
\hline Share & 15 & $47 \%$ \\
\hline Resource/energy efficiency & 14 & $44 \%$ \\
\hline Life cycle & 13 & $41 \%$ \\
\hline Reuse & 12 & $38 \%$ \\
\hline Loop & 12 & $38 \%$ \\
\hline Virtualise & 9 & $28 \%$ \\
\hline Regenerate & 7 & $22 \%$ \\
\hline Exchange & 6 & $19 \%$ \\
\hline Circular business models & 3 & $9 \%$ \\
\hline Reverse logistic & 3 & $9 \%$ \\
\hline
\end{tabular}

\section{Definition of Industry 4.0}

There are various explanations of Industry 4.0, and consensus regarding the technologies that should be included is lacking (Rosa, et al., 2020). This finding leads to the perception that Industry 4.0 as used as a buzzword (Rejikumar et al. 2019). There is no one definition that is more frequently quoted in the selected papers. The authors of the analysed articles explain this concept by stressing different contexts. In one perspective, Industry 4.0 is referred to as the Fourth Industry Revolution (Okorie et al., 2018; Rajput \& Singh, 2019a). Other references are made to smart production, smart manufacturing, smart logistics and smart factory (Cezarino, Liboni, Oliveira Stefanelli, Oliveira, \& Stocco, 2019; Jabbour, Jabbour, Filho, \& Roubaud, 2018; Yadav, 2020; Chauhan \& Singh (2019). "Smart" refers to the digitalisation of manufacturing systems by using ICT. Such systems primarily include digital value chains as a result of the digital transformation of the manufacturing environment (de Oliveira \& Soares, 2017; Martin-Gomez, Aguayo-Gonzalez, \& Luque, 2019). This digitalised system works due to the ability to communicate with its actors and parts (machines, workers, suppliers, etc.). This system is also called a cyber-physical system (CPS) as it reflects "an integration of manufacturing operation systems and information and communication technologies" (Okorie et al., 2018). Ruohomma et al. provided the following concise definition: "Industry 4.0 describes the organisation of production processes based on technology and devices autonomously communicating with each other along the value chain: a model of the 'smart' factory of the future where computer-driven systems monitor physical processes, create a virtual copy of the physical world and make decentralised decisions based on self-organisation mechanisms" (Ruohomaa, Kantola, \& Salminen, 2018, p. 30). However, there is no commonly accepted definition. Among the explanations, we note the elaboration by Okorie et al. (2018) who refer to Lu's definition as follows: "integrated, adapted, optimised, service-oriented, and interoperable manufacturing process which is correlate with algorithms, big data, and high technologies" (Lu, 2017, p. 3).

The above explanations demonstrate the approach used to define the Industry 4.0 concept through a list of constituting technologies or tools. The content analysis of 
the selected papers presents different typologies. We established our own list of Industry 4.0 technologies based on review papers (Okorie et al., 2018; Rosa et al., 2020) and used this list as coding categories. The list comprises Additive Manufacturing, Big Data and Analytics, Cloud Manufacturing, CPSs, IoT, and Other (none of the above).

The most frequently mentioned key Industry 4.0 technologies include the IoT (19 mentions), big data and analytics (17 mentions), CPSs (11 mentions), additive manufacturing, such as 3D printing (9 mentions), and cloud manufacturing (9 mentions). Authors have also added the following to this list: artificial intelligence (AI), sensors as part of CPS, and additive manufacturing, such as 3D printing. Almost all authors refer to one of these tools. A more extensive list of Industry 4.0 technologies was compiled by Cezarino et al. (2019). This list contains augmented reality, the IoT, 3D printing, mobile devices, AI, CPS, big data, analytics, and smart sensors. The list contains different types of technological and information solutions that are difficult to classify, i.e., is a sensor a separate tool or a part of CPS? Is radio-frequency identification (RFID) a new tool or simply a resource used by the IoT? The analysis of the selected papers also demonstrates discussions of different aspects with the most often reference to the IoT and big data. We observed that the papers discussing Industry 4.0 technologies refer mainly to the following two tools: IoT and Big Data and Analytics.

\section{Findings, Results and Discussion}

To answer RQ1 (what are the relationships between CE and Industry 4.0?), we searched for an explanation of the direction of this relation. In all analysed papers, the observation was as follows: Industry 4.0 leads to CE. Pham et al. (2019) call this trend Industry 4.0-Supported CE. Additionally, some authors perceive these concepts as two sides of the same coin (Garcia-Muina et al., 2018), while other authors propose a synergistic system or symbiosis. According to Cezarino et al., "digital trends create opportunities for sustainable value chain" and a "sustainable value chain promotes opportunities to digital trends" (Cezarino et al., 2019, p. 9). Such integrative perspectives are found in 5 of the 32 analysed papers. Nevertheless, the relations between $\mathrm{CE}$ and Industry 4.0 have not been thoroughly explored as noted by Jabbour et al. (2018), Chauhan \& Singh (2019) and Pham et al. (2019). The synthesis provided by Rosa et al. (2020) demonstrates that the following two perspectives appear due to the lack of a unified perspective: Industry 4.0-based and CE-based resulting in digital CE and circular Industry 4.0.

Studies concerning digital technologies and their uses for $\mathrm{CE}$ purposes have revealed that these tools are used for a particular goal without a broader context (Okorie et al., 2018). For example, digital sensors are used for remanufacturing in vehicle engines. A systematic literature review revealed the diversified impact of Industry 4.0 technology on businesses (Rosa et al., 2020).

Table 5 classifies the analysed papers according to the type of research (theoretical and empirical). The relations between $\mathrm{CE}$ and Industry 4.0 are more evident in the theoretical articles. The most common CE connections with Industry 4.0 technologies occur in reference to the IoT and Big Data and Analytics. These concepts have the strongest relationship with recycle and optimise and the weakest relationship with the Circular Business Model. Additive Manufacturing is the least analysed technology with reference to CE in empirical articles. In the empirical studies, the strongest connections were found between the IoT and the entire 3Rs strategy. There were no empirical links between Industry 4.0 technologies and reverse logistic; however, only single links exist in the theoretical articles.

CE and Industry 4.0 Technologies

Table 5

\begin{tabular}{|c|c|c|c|c|c|c|c|c|c|c|c|c|c|c|c|c|}
\hline \multirow[b]{2}{*}{ CE variables } & \multicolumn{3}{|c|}{$\begin{array}{c}\text { Additive } \\
\text { Manufacturing }\end{array}$} & \multicolumn{3}{|c|}{$\begin{array}{c}\text { Big Data } \\
\text { and Analytics }\end{array}$} & \multicolumn{3}{|c|}{$\begin{array}{c}\text { Cloud } \\
\text { Manufacturing }\end{array}$} & \multicolumn{3}{|c|}{$\begin{array}{c}\text { Cyber-Physical } \\
\text { Systems }\end{array}$} & \multicolumn{3}{|c|}{$\begin{array}{c}\text { Internet } \\
\text { of Things }\end{array}$} & \multirow[b]{2}{*}{ Sum of all } \\
\hline & $\mathrm{E}^{*}$ & $\mathrm{~T}^{* *}$ & All & $E$ & $\mathrm{~T}$ & All & $E$ & $\mathrm{~T}$ & All & $\mathrm{E}$ & $\mathrm{T}$ & All & $\mathrm{E}$ & $\mathrm{T}$ & All & \\
\hline Regenerate & 1 & 2 & 3 & 1 & 3 & 4 & 1 & 2 & 3 & 0 & 2 & 2 & 1 & 3 & 4 & 16 \\
\hline Share & 1 & 4 & 5 & 4 & 4 & 8 & 3 & 3 & 6 & 3 & 3 & 6 & 5 & 4 & 9 & 34 \\
\hline Optimise & 1 & 6 & 7 & 3 & 6 & 9 & 2 & 5 & 7 & 3 & 5 & 8 & 4 & 6 & 10 & 41 \\
\hline Loop & 1 & 4 & 5 & 3 & 4 & 7 & 1 & 3 & 4 & 3 & 3 & 6 & 3 & 4 & 7 & 29 \\
\hline Virtualise & 1 & 4 & 5 & 2 & 4 & 6 & 1 & 3 & 4 & 2 & 3 & 5 & 1 & 5 & 6 & 26 \\
\hline Exchange & 1 & 2 & 3 & 2 & 3 & 5 & 1 & 2 & 3 & 1 & 2 & 3 & 1 & 3 & 4 & 18 \\
\hline Reduce & 0 & 4 & 4 & 3 & 6 & 9 & 1 & 4 & 5 & 3 & 4 & 7 & 6 & 5 & 11 & 36 \\
\hline Reuse & 0 & 4 & 4 & 3 & 5 & 8 & 1 & 3 & 4 & 3 & 4 & 7 & 4 & 5 & 9 & 32 \\
\hline Recycle & 1 & 5 & 6 & 6 & 6 & 12 & 2 & 4 & 6 & 4 & 5 & 9 & 8 & 5 & 13 & 46 \\
\hline Circular Business Models & 0 & 1 & 1 & 0 & 2 & 2 & 0 & 1 & 1 & 0 & 1 & 1 & 1 & 2 & 3 & 8 \\
\hline LCA & 1 & 5 & 6 & 2 & 6 & 8 & 1 & 4 & 5 & 1 & 5 & 6 & 3 & 5 & 8 & 33 \\
\hline Reverse Logistics & 0 & 3 & 3 & 0 & 2 & 2 & 0 & 1 & 1 & 0 & 2 & 2 & 0 & 3 & 3 & 11 \\
\hline Sum & 8 & 44 & 52 & 29 & 51 & 80 & 14 & 35 & 49 & 23 & 39 & 62 & 37 & 50 & 87 & 16 \\
\hline
\end{tabular}

Key: *E-empirical papers, ${ }^{* *} T$-theoretical, conceptual and review papers

Another synthesis of the common areas in $\mathrm{CE}$ and Industry 4.0 is provided by Jabbour et al. (2018). Table 6 proposed by the Ellen McArthur Foundation (2015a). This framework represents the actions leading to the implementation of CE. Jabbour et al. established the relations between sustainable operations management (design of products, production of products, and presents the relations at a more detailed level of $\mathrm{CE}$ expressed by the ReSOLVE framework logistics/reverse logistics) and key Industry 4.0 tools. The matrix created based on their proposition indicates that the most significant is the IoT due to its broad coverage of ReSOLVE parts (5 of 6 actions), followed by cloud manufacturing (3), while CPS and additive manufacturing 
have lesser impacts on CE. The data derived from our research confirm the importance of the IoT as a key Industry 4.0 technology that is adequate for the adaption of the CE strategy. We observe that the use of CPSs is more frequently examined than the use of additive management. Cloud computing is studied to support resource efficiency (Optimise).

Matrix of the Relations between CE and Industry 4.0 main Tools

\begin{tabular}{|c|c|c|c|c|}
\hline & \multicolumn{4}{|c|}{ Key Industry 4.0 Tools } \\
\hline ReSOLVE & Internet of Things & Cloud manufacturing & Cyber-physical systems & Additive manufacturing \\
\hline Regenerate & $\begin{array}{ll}\text { - } & \text { Design of products } \\
\text { - } & \text { Production of products }\end{array}$ & & & \\
\hline Share & $\begin{array}{ll}\text { - } & \text { Design of products } \\
\text { - } & \text { Production of products } \\
\text { - } & \text { Logistics/reverse logistics }\end{array}$ & $\begin{array}{l}\text { - Design of products } \\
\text { - } \quad \text { Production of products }\end{array}$ & & \\
\hline Optimise & $\begin{array}{ll}\text { - } & \text { Production of products } \\
\text { - } & \text { Logistics/reverse logistics }\end{array}$ & & Production of products & \\
\hline Loop & $\begin{array}{ll}\text { - } & \text { Design of products } \\
\text { - } & \text { Production of products } \\
\text { - } & \text { Logistics/reverse logistics }\end{array}$ & Logistics/reverse logistics & Production of products & \\
\hline Virtualise & $\begin{array}{ll}\text { - } & \text { Design of products } \\
\text { - } & \text { Production of products } \\
\text { - } & \text { Logistics/reverse logistics }\end{array}$ & $\begin{array}{l}\text { - Design of products } \\
\text { - Production of products }\end{array}$ & & Production of products \\
\hline Exchange & & & & $\begin{array}{l}\text { Design of products } \\
\text { Production of products }\end{array}$ \\
\hline
\end{tabular}

Source: based on (Jabbour et al., 2018, p. 9).

A review of the relations between the CE and Industry 4.0 merging macro and micro terms reveals the most frequent associations studied in research papers. We synthesised the findings reported by Rosa et al. (2020) and present these findings as a heat map of the relations between $\mathrm{CE}$ and Industry 4.0 technologies. We aligned the number of references to particular items associated with key terms in descending order (Table 7).Studies adopting a generic perspective (any Industry 4.0 technologies) match digital transformation and circular business models. More specific Industry 4.0 technologies have different influences on CE-related areas and the fit of these areas with these technologies. Our findings are inconsistent with this paper but expose that the increased role of the IoT and Big Data is more strongly related to the reuse and recycle approach.

Table 7

Heat Map of the Relations between CE and Industry 4.0 Technologies

\begin{tabular}{|c|c|c|c|c|c|c|c|}
\hline CE-related items & $\begin{array}{c}\text { Any I4.0 } \\
\text { Technology }\end{array}$ & $\begin{array}{c}\text { Additive } \\
\text { Manufacturing }\end{array}$ & Simulation & IoT & $\begin{array}{c}\text { Big Data } \\
\text { and Analytics }\end{array}$ & $\begin{array}{c}\text { Cyber-physical } \\
\text { Systems }\end{array}$ & Total \\
\hline Lifecycle management & 3 & 9 & 6 & 7 & 2 & 7 & 34 \\
\hline Digital transformation & 13 & 5 & & 3 & 4 & & 25 \\
\hline Circular business models & 11 & 3 & 6 & 2 & 2 & & 24 \\
\hline Resource efficiency & 8 & 2 & 2 & 4 & 3 & 1 & 20 \\
\hline Remanufacturing & 7 & 4 & 4 & 1 & 1 & 1 & 18 \\
\hline Smart services & 2 & & 2 & 3 & 3 & 7 & 17 \\
\hline Supply chain management & 1 & & 5 & 2 & 1 & & 9 \\
\hline Recycling & & 6 & 1 & & 1 & & 8 \\
\hline Disassembly & 1 & & & & 1 & & 2 \\
\hline Reuse & & 1 & & & & & 1 \\
\hline Total & 46 & 30 & 26 & 22 & 18 & 16 & 158 \\
\hline
\end{tabular}

Source: based on (Rosa et al., 2020).

The following research question is RQ2 (What are the key spheres necessary for introducing CE supported by Industry 4.0 technologies?). The authors present a diversified view of this subject. A synthesis of the perspectives (Table 8) emerging in the studied papers allows for distinguishing the following perspectives. The largest number of references referred to sustainable supply chain (9 times), followed by smart production (7), issues related to CE and Industry 4.0 (7), business model (5), and life cycle management (3). One paper addresses education.

Regarding the organisation level, smart and sustainable manufacturing appear when CE appears
(Jabbour et al., 2018; Yang et al., 2018). The next more general perspective, which still remains within the boundaries of the organisation, is the business model supporting $\mathrm{CE}$, which can be called a circular business model (Bressanelli, Adrodegari, Perona, \& Saccani, 2018a; Garcia-Muina et al., 2018; Nascimento et al., 2019). Crossing the organisational boundaries leads to sustainable supply chains (Manavalan \& Jayakrishna, 2019; Martín-Gomez, Aguayo-Gonzalez, \& Luque, 2019; Rajput \& Singh, 2019a) and product life management (de Oliveira \& Soares, 2017; Kuo-Yi Lin, 2018). A more general issue appearing in the analysed papers is the 
conceptual model of merging Industry 4.0 and $\mathrm{CE}$ (Okorie et al., 2018; Ming-Lang Tseng et al., 2018) and the barriers to and limitations of $\mathrm{CE}$ and Industry 4.0 (Cezarino et al., 2019; Rajput \& Singh, 2019b). In this context, we establish an educational programme aiming to train bioengineering ICT experts (Ruohomaa et al., 2018).
An analysis of the descriptions of these objects allows us to elaborate on this issue, leading to the following inferences:

- Smart production refers to the remanufacturing process (Yang et al., 2018) and focuses on examples that use Industry 4.0 technologies for production.

Key Spheres Necessary for Introducing CE Supported by Industry 4.0 Technologies

Table 8

\begin{tabular}{|c|c|c|}
\hline Sphere & $\begin{array}{l}\text { Numbers } \\
\text { of sources }\end{array}$ & Sources \\
\hline $\begin{array}{l}\text { Sustainable supply } \\
\text { chain (SSC) }\end{array}$ & 9 & $\begin{array}{l}\text { Belaud et al. (2019), Chauhan \& Singh (2019), Dau et al. (2019), Dev et al. (2020), Manavalan \& } \\
\text { Jayakrishna, (2019), Martín-Gomez et al., (2019), Rajput \& Singh (2019a), Sarc et al. (2019), Yadav et al., } \\
\text { (2020) }\end{array}$ \\
\hline Smart production & 7 & $\begin{array}{l}\text { Bag et al. (2020), Cezarino, et al. (2019), Jabbour et al., (2018), Kouhizadeh, Zhu \& Sarkis (2019), Tseng et } \\
\text { al. (2018), Tseng et al. (2019), Yang et al., (2018) }\end{array}$ \\
\hline $\begin{array}{l}\text { CE and Industry } 4.0 \text { : } \\
\text { relations, barriers, } \\
\text { and attributes }\end{array}$ & 7 & $\begin{array}{l}\text { Halse \& Jæger (2019), Karjalainen et al. (2019), Pham et al. (2019), Rejikumar et al. (2019), Rosa et al. } \\
\text { (2020), Rajput \& Singh (2019b), Okorie et al. (2018) }\end{array}$ \\
\hline Business model & 5 & $\begin{array}{l}\text { Bressanelli et al., (2018a), Bressanelli et al., (2018b), Chauhan, Sharma, \& Singh (2019), Garcia-Muina et al., } \\
\text { (2018), Nascimento et al., (2019) }\end{array}$ \\
\hline $\begin{array}{l}\text { Life cycle and } \\
\text { product design }\end{array}$ & 3 & de Oliveira \& Soares (2017), Garcia-Muina et al., (2019), Lin (2018) \\
\hline Education & 1 & Ruohomaa, Kantola, \& Salminen (2018) \\
\hline
\end{tabular}

- The sustainable supply chain perspective crosses organisational boundaries and is discussed in terms of the whole industry. The idea is to close the loop within the chain by using Industry 4.0 tools (Rajput \& Singh, 2019a). This perspective also explains why industry is among the most frequent levels of analysis.

- Business models are presented not only as circular business models (Garcia-Muina et al., 2018) or productservice systems (PSS) but also as servitised business models (Bressanelli et al., 2018b), which enables comparisons to the company level of analysis. This perspective concentrates on the efforts of one company transitioning from a linear operational mode to a circular mode.

- Life cycle management is mentioned as product life management (de Oliveira \& Soares, 2017) and a part of the more general life cycle (Garcia-Muina et al., 2018).

\section{Conclusions}

This paper discusses recent articles addressing the following two topics simultaneously: Industry 4.0 and CE. This paper demonstrates the novelty of the approach aiming to determine their synthesis and synergy. Our study delivers new insight into the body of knowledge regarding jointly considered Industry 4.0 and CE. This study fills the knowledge gap regarding the level at which the coexistence of these two ideas occurs, the main enablers, the research focus, and the relations between the detailed parts of the studied phenomena. Moreover, this paper concentrates on concepts that are interpreted broadly in the current literature. Other studies, such as Okorie et al. (2018), address this issue from a specific solution or part constituting CE and Industry 4.0, such as digitisation. The comprehensive view expressed in this paper not only enriches the current debate regarding the relations between $\mathrm{CE}$ and Industry 4.0 but also discusses its directions. In particular, the most significant area of study is the sustainable supply chain as closing the loop is more efficient from the perspective of the whole economy. This study explains the dominance of the industry level of analysis. These main findings bridge CE and Industry 4.0 within a single company. This study explains how CE can be introduced using Industry 4.0 tools and contributes to a better explanation of the research problem associated with implementation areas of CE in business practices.

However, this study shows the lack of a common definition of Industry 4.0 compared to CE. The following conclusion is drawn, i.e., the diverse set of Industry 4.0 tools impedes a clear indication of how to use these tools at the industry level. These tools are very specific in terms of use in particular areas, while industry is more general in terms of the factors hampering exemplifications.

The third conclusion is derived from Table 5. The most significant Industry 4.0 tool is the IoT. This tool can be used in all operations management processes and enables almost all actions associated with $\mathrm{CE}$. The transition to a $\mathrm{CE}$ creates the possibility to gain a lasting competitive advantage as this approach protects business entities from resource shortages and price fluctuations. This transition also offers the opportunity to develop innovation while pursuing sustainable production and consumption.

Our findings enrich existing knowledge regarding the relations between $\mathrm{CE}$ and Industry 4.0 derived from previous literature reviews. The results show the changing role of the IoT and Big Data in implementing CE strategies compared to previous analyses (Rosa et al., 2020). The data suggest that the most researched areas of the ReSOLVE framework are Share and Optimise, and applications of the IoT and Big Data Analytics are the most frequent used compared to other dimensions.

Our paper shows that the $\mathrm{CE}$ and Industry 4.0 are directly linked. This article identifies the key CE implementation spheres supported by Industry 4.0 technologies, showing the importance of industry and sustainable supply chains with particular emphasis on the IoT and Big Data Analytics. This study could help managers and policy makers understand the principles of implementing 
technologies that support the conceptualisation of Industry 4.0. This study can be applied to all operational management processes, enabling the selection of existing CE links with Industry 4.0. Also it can be helpful for policymakers to create action plans for shifting industries to be more circular by using digital technologies at the country level.

Additionally, this article demonstrates how CE can be implemented using Industry 4.0 tools and contributes to a better understanding of the implementation of $\mathrm{CE}$ in business practices. The transition to a $\mathrm{CE}$ creates the opportunity to gain a lasting competitive advantage because this approach protects business entities against resource shortages and price fluctuations. This transition also offers the opportunity to develop innovation while striving for sustainable production and consumption.

The increase in available data associated with the use of Industry 4.0 tools gives managers not only prospects for improving existing processes but also prospects for change. Therefore, the analysis carried out provides a basis for managers to develop the initiative and practice of a successful transition to Industry 4.0.

To gain the potential benefits of Industry 4.0, managers need to consider digitisation as an opportunity to transform their business models due to the expectations of society, which requires that production plants take the direction of a CE. Managers can choose their CE goals and accordingly identify the set of Industry 4.0 technologies that best support their strategy. Thus, managers can use this article's conceptual framework to determine which CE criteria are the most commonly linked to Industry 4.0.

\section{Limitations and Direction for Future Research}

Similar to all studies, this study has some limitations. The main limitation is that the analysed sources were derived only from peer-reviewed sources even though $\mathrm{CE}$ and Industry 4.0 have been jointly discussed in the grey literature, such as reports and blog entries. Therefore, it could be interesting to enrich the analysis by adding nonsyndicated papers.

The following limitation results from the blurred concept of Industry 4.0. Okorie et al. (2018) chose another approach in their systematic literature review. These authors profiled the search strings by exchanging key terms related to their characteristics, such as reduce next to $\mathrm{CE}$ and digital technology as synonym of Industry 4.0. The broader approach used in our paper limited the number of articles related to the topic. This study also demonstrates that studies of CE and industry at a more general level are in their infancy. We suggest that future studies focus on interorganisational relations, the supply chain or the product life cycle to search for an answer to the following question: what does Industry 4.0 mean for the supply chain? (Tjahjono, Esplugues, Ares, \& Pelaez, 2017). We also observed that despite the importance of the driving role of legislation regarding $\mathrm{CE}$ and the relations between industries and government, these topics did not appear in the analysed papers. Therefore, this area of interactions should also be investigated in future research.

\section{Financial Disclosure}

This project was financed by the Ministry of Science and Higher Education within the "Regional Initiative of Excellence" Programme for 2019-2022. Project no: 021/RID/2018/19. Total financing: 11897 131,40 PLN

\section{References}

Bag, S., Wood, L. C., Mangla, S. K., \& Luthra, S. (2020). Procurement 4.0 and its implications on business process performance in a circular economy. Resources, Conservation and Recycling, 152, 1-14. https://doi.org/10. 1016/j.resconrec.2019.104502

Belaud, J.-P., Prioux, N., Vialle, C., \& Sablayrolles, C. (2019). Big data for agri-food 4.0: Application to sustainability management for by-products supply chain. Computers in Industry, 111, 41-50. https://doi.org/10.1016/ j.compind.2019.06.006

Chauhan, C., Sharma, A., \& Singh, A. (2019). A SAP-LAP linkages framework for integrating Industry 4.0 and circular economy. Benchmarking. https://doi.org/10.1108/BIJ-10-2018-0310

Chauhan, Chetna, \& Singh, A. (2018). A review of Industry 4.0 in supply chain management studies. Journal of Manufacturing Technology Management. https://doi.org/10.1108/JMTM-04-2018-0105

Dau, G., Scavarda, A., Scavarda, L. F., \& Taveira Portugal, V. J. (2019). The Healthcare Sustainable Supply Chain 4.0: The Circular Economy Transition Conceptual Framework with the Corporate Social Responsibility Mirror. Sustainability, 11(12). https://doi.org/10.3390/su11123259

de Oliveira, S. F., \& Soares, A. L. (2017). A PLM vision for circular economy. IFIP Advances in Information and Communication Technology, 506, 591-602. https://doi.org/10.1007/978-3-319-65151-4_52

Dev, N. K., Shankar, R., \& Qaiser, F. H. (2020). Industry 4.0 and circular economy: Operational excellence for sustainable reverse supply chain performance. Resources, Conservation and Recycling, 153, 104583. https://doi.org/10. 1016/j.resconrec.2019.104583

Ellen MacArthur Foundation. (2012). Towards a Circular Economy - Economic and Business Rationale for an Accelerated Transition (No. 1). Coves: Ellen MacArthur Foundation. 
Ellen MacArthur Foundation. (2015a). Delivering the Circular Economy. A Toolkit for Policymakers. Coves: Ellen MacArthur Foundation.

Ellen MacArthur Foundation. (2015b). Towards a Circular Economy - Economic and Business Rationale for an Accelerated Transition. Coves: Ellen MacArthur Foundation.

Garcia-Muina, F. E., González-Sánchez, R., Ferrari, A. M., Volpi, L., Pini, M., Siligardi, C., \& Settembre-Blundo, D. (2019). Identifying the equilibrium point between sustainability goals and circular economy practices in an Industry 4.0 manufacturing context using eco-design. Social Sciences, 8(8). https://doi.org/10.3390/socsci8080241

Garcia-Muina, F., Gonzalez-Sanchez, R., Ferrari, A. M., \& Settembre-Blundo, D. (2018). The paradigms of Industry 4.0 and circular economy as enabling drivers for the competitiveness of businesses and territories: The case of an Italian ceramic tiles manufacturing company. Social Sciences, 7(12). https://doi.org/10.3390/socsci7120255

Geissdoerfer, M., Savaget, P., Bocken, N. M. P., \& Hultink, E. J. (2017). The Circular Economy - A new sustainability paradigm? Journal of Cleaner Production, 143, 757-768. https://doi.org/10.1016/j.jclepro.2016.12.048

Halse, L. L., \& Jæger, B. (2019). Operationalizing Industry 4.0: Understanding Barriers of Industry 4.0 and Circular Economy. IFIP Advances in Information and Communication Technology, 567, 135-142. https://doi.org/10. 1007/978-3-030-29996-5_16

Jabbour, A. B. L. de S. J., Jabbour, C. J. C., Filho, M. G., \& Roubaud, D. (2018). Industry 4.0 and the circular economy: A proposed research agenda and original roadmap for sustainable operations. Annals of Operations Research, 270(1/2), 273-286. https://doi.org/10.1007/s10479-018-2772-8

Karjalainen, J., Heinonen, S., \& Shaw, M. (2019). Peer-to-peer and circular economy principles in the fourth industrial revolution (4IR)-New risks and opportunities. Proceedings of the 27th International Conference on the Domestic Use of Energy, DUE 2019, 220-230.

Kirchherr, J., Reike, D., \& Hekkert, M. (2017). Conceptualizing the circular economy: An analysis of 114 definitions. Resources, Conservation and Recycling, 127, 221-232. https://doi.org/10.1016/j.resconrec.2017.09.005

Knudsen, M. S., \& Kaivo-oja, J. (2018). Bridging Industry 4.0 and Circular Economy: A new research agenda for Finland? Retrieved 16 March 2019, from Tulevaisuuden tutkimuskeskuksen blogi website: https://ffrc.wordpress.com/ 2018/09/ 12/bridging-industry-4-0-and-circular-economy/

Kouhizadeh, M., Zhu, Q., \& Sarkis, J. (2019). Blockchain and the circular economy: Potential tensions and critical reflections from practice. Production Planning \& Control. https://doi.org/10.1080/09537287.2019.1695925

Lin, K. Y. (2018). User experience-based product design for smart production to empower industry 4.0 in the glass recycling circular economy. Computers and Industrial Engineering, 125, 729-738. https://doi.org/10.1016/j. cie.2018.06.023

Lu, Y. (2017). Industry 4.0: A survey on technologies, applications and open research issues. Journal of Industrial Information Integration, 6, 1-10. https://doi.org/10.1016/j.jii.2017.04.005

Manavalan, E., \& Jayakrishna, K. (2019). An Analysis on Sustainable Supply Chain for Circular Economy. Procedia Manufacturing, 33, 477-484. https://doi.org/10.1016/j.promfg.2019.04.059

Martin-Gomez, A., Aguayo-Gonzalez, F., \& Luque, A. (2019). A holonic framework for managing the sustainable supply chain in emerging economies with smart connected metabolism. Resources Conservation And Recycling, 141, 219232. https://doi.org/10.1016/j.resconrec.2018.10.035

Nascimento, D. L. M., Alencastro, V., Quelhas, O. L. G., Caiado, R. G. G., Garza-Reyes, J. A., Lona, L. R., \& Tortorella, G. (2019). Exploring Industry 4.0 technologies to enable circular economy practices in a manufacturing context. Journal of Manufacturing Technology Management, 30(3), 607-627. https://doi.org/10.1108/JMTM-03-2018-0071

Okorie, O., Salonitis, K., Charnley, F., Moreno, M., Turner, C., \& Tiwari, A. (2018). Digitisation and the Circular Economy: A Review of Current Research and Future Trends. Energies, 11(11). https://doi.org/10.3390/en11113009

Pham, T. T., Kuo, T. C., Tseng, M. L., Tan, R. R., Tan, K., Ika, D. S., \& Lin, C. J. (2019). Industry 4.0 to accelerate the circular economy: A case study of electric scooter sharing. Sustainability, 11(23). https://doi.org/10.3390/ su1 1236661

Prieto-Sandoval, V., Jaca, C., \& Ormazabal, M. (2018). Towards a consensus on the circular economy. Journal of Cleaner Production, 179, 605-615. https://doi.org/10.1016/j.jclepro.2017.12.224

Rajput, S., \& Singh, S. P. (2019a). Industry 4.0 - challenges to implement circular economy. Benchmarking. https://doi.org/10. 108/BIJ-12-2018-0430 
Rajput, S., \& Singh, S. P. (2019b). Connecting circular economy and industry 4.0. International Journal of Information Management, 49, 98-113. https://doi.org/10.1016/j.ijinfomgt.2019.03.002

Rejikumar, G., Sreedharan V, R., Arunprasad, P., Persis, J., \& K.M, S. (2019). Industry 4.0: Key findings and analysis from the literature arena. Benchmarking, 26(8), 2514-2542. https://doi.org/10.1108/BIJ-09-2018-0281

Rosa, P., Sassanelli, C., \& Terzi, S. (2019). Circular Business Models versus circular benefits: An assessment in the waste from Electrical and Electronic Equipments sector. Journal of Cleaner Production, 231, 940-952. https://doi.org/10.1016/j.jclepro.2019.05.310

Ruohomaa, H., Kantola, J., \& Salminen, V. (2018). Value network development in industry 4.0 environment. Advances in Intelligent Systems and Computing, 594, 28-39. https://doi.org/10.1007/978-3-319-60372-8_4

Sarc, R., Curtis, A., Kandlbauer, L., Khodier, K., Lorber, K. E., \& Pomberger, R. (2019). Digitalisation and intelligent robotics in value chain of circular economy oriented waste management - A review. Waste Management, 95, 476492. https://doi.org/10.1016/j.wasman.2019.06.035

Schwab, K. (2016). The fourth industrial revolution. Geneva: World Economic Forum.

The internet of packaging is the future of consumer brands. (2019). Retrieved 24 May 2019, from Water.io website: https://www.water-io.com/internet-of-packaging

Tjahjono, B., Esplugues, C., Ares, E., \& Pelaez, G. (2017). What does Industry 4.0 mean to Supply Chain? Procedia Manufacturing, 13, 1175-1182. https://doi.org/10.1016/j.promfg.2017.09.191

Tseng, M. L., Chiu, A. S. F., Chien, C. F., \& Tan, R. R. (2019). Pathways and barriers to circularity in food systems. Resources, Conservation \& Recycling, 143, 236-237.

Tseng, M. L., Tan, R. R., Chiu, A. S. F., Chien, C. F., \& Kuo, T. C. (2018). Circular economy meets industry 4.0: Can big data drive industrial symbiosis? Resources, Conservation and Recycling, 131, 146-147. https://oi.org/10. 1016/j.resconrec.2017.12.028

WEF (2019). Harnessing the Fourth Industrial Revolution for the Circular Economy. Geneva: World Economic Forum.

Yadav, G., Luthra, S., Jakhar, S. K., Mangla, S. K., \& Rai, D. P. (2020). A framework to overcome sustainable supply chain challenges through solution measures of industry 4.0 and circular economy: An automotive case. Journal of Cleaner Production, 254, 120112. https://doi.org/10.1016/j.jclepro.2020.120112

Yang, S., Raghavendra, M. R. A., Kaminski, J., \& Pepin, H. (2018). Opportunities for industry 4.0 to support remanufacturing. Applied Sciences, 8(7). https://doi.org/10.3390/app8071177

The article has been reviewed.

Received in November 2019; accepted in October 2020.

This article is an Open Access article distributed under the terms and conditions of the Creative Commons Attribution 4.0 (CC BY 4.0) License (http://creativecommons.org/licenses/by/4.0/). 